\title{
The Concept of Apostasy in the Epistle to the Hebrews*
}

by D. H. Tongue

THE SUBJECT of Christian apostasy is at once both a personal and an academic one. Every young Christian is at some time exercised by the peril of 'crucifying the Son of God afresh'; and some backsliding believers try in vain to find the place of conscious repentance. The personal issue can best be resolved however, not by isolating it, but by associating it with a sound academic approach to the document which gave it birth. It is proposed in this paper to discuss briefly certain theories about the destination of the Epistle, in order to establish the identity of the readers. Then in the light of these theories we shall attempt to analyse the more familiar passages dealing with apostasy: their vital bearing on our own personal Christian lives must dominate our thinking throughout.

The more popular course will probably always be to picture the readers as Palestinian Jews. How far this theory is traditional is doubtful; since we cannot prove the Epistle was known by the title To the Hebrews before A.D. 200 (Clement of Alex.). But a theory which postulates the close proximity of the Jerusalem Temple holds an obvious advantage over others in a document where sacrificial ordinances are so much in the foreground. Admittedly there was another Temple at Leontopolis; admittedly the ritual details are really based on the Tabernacle; yet so powerful was the influence of the Jerusalem Temple on early Christian thought that writers like Westcott feel bound to conclude that the society to whom the letter was addressed lived in Jerusalem or its neighbourhood.

On this theory, apostasy is caused by the ever widening breach between Church and Synagogue. Hebrew Christians who began as the Nazarene Sect within Judaism, and enjoyed the support of the Pharisees and the mass of the Jewish people,

* A paper read at the New Testament Study Group, July 1959. 
became the object of Jewish attack at the time of Stephen's martyrdom. At first they

'joyfully accepted the plundering of their property'

but years of bitter family feud between Church and Synagogue demanded powers of endurance greater than many Hebrew Christians possessed. They abandoned their faith in the Messiahship of Jesus, and shrank back into the fold of Judaism (Heb. x.39) just as Jerusalem's own day of retribution was approaching in A.D. 70.

Before leaving this Palestinian theory, we may perhaps refer to a suggestion made by C. Sandegren (Evangelical Quarterly, October 1955) that the Addressees of Hebrews were the 'great company of the Priests who were obedient to the Faith' in Acts vi.7. He notes more especially the 278 O.T. references in the Epistle, the demand that all should be teachers (Heb. v. I2) which contrasts so strangely with the word 'be not many teachers' in James iii. I, and the references to property and hospitality which the Mosaic Law (Lev. xxv.29) safeguarded to her Priests. The Jewish authorities, he suggests, would naturally make a desperate bid to win back these key apostates from Judaism, and re-instate them in the Jerusalem Temple; and the original title may well have been, according to Sandegren, not 'PROS HEBRAIOUS' but 'PROS HIEREIS'. It might even be possible to modify this theory along lines suggested by J. Allegro, and regard the great company of Priests as emanating not from Jerusalem but from Qumran; they might be the true sons of Zadok there resident; the spiritual élite of both the Pharisees and Sadducees, returning from their 'House of Exile' to the Holy City, in readiness to assume control of the Temple at the Parousia of the Priest of Aaron and Israel. Their subsequent apostasy would account for the fact that the Essenes are later mentioned by Hippolytus among seven sects of the Jews who were hostile to the Christian Faith.

If the addressees of Hebrews were Priests, whether orthodox or schismatic, they would have been dominated by the concept of the Covenant relationship. Christianity for them would have consisted in entry into the new Messianic Covenant; apostasy 
in the sacriligeous breaking of that Covenant. A few lines from the Manual of Discipline will serve to stress the priestly regard for the sacred Covenant:-

'Cursed be he who enters into this Covenant,

And puts before himself that which causes

him to stumble in sin;

So as to backslide away from God.

May all the curses of this Covenant cling to him;

May he be cut off from the midst of the Sons of Light;

When he backslides from following after God;

May He place his lot in the midst of the eternally cursed.'

(Dupont Summer, pp. 94-95)

This same horror of despising the Covenant would seem to underlie the passage in Hebrews x.28-3 I.

'A man who violated the Law of Moses died without mercy ... How much worse punishment will be deserved by the man who has spurned the Son of God, and profaned the blood of the Covenant by which he was sanctified?'

Many scholars in recent years have turned away from Palestine and portrayed the Hebrews as a community of Jewish Christians at Rome; possibly a wing of a Jewish Christian congregation in the city. They were drifting away from their Christian moorings back into Judaism for various reasons such as:-

(a) Disappointment over the Parousia (Heb. x.35-8).

(b) The growing pressure of persecution.

(c) The increased strength of Jewish propaganda at home under the Flavian emperors.

(d) The sentimental revulsion produced in Jewish hearts by the fall of Jerusalem.

Their apostasy amounted in fact to a hankering after the ancient Biblical records of the Tabernacle and the cultus. They had 'tasted the powers of the age to come' and then developed a perverse thirst for very weak pre-Mosaic grapefruit. Although some who argue along these lines postulate a late date after A.D. 7o for Hebrews, this is not essential to the position. We know from writers like Philo and Horace that the Diaspora Jews of the ist century avoided Temple worship, and revived the patriarchal pre-Mosaic worship of the time of Abraham. They possessed, moreover, a notable zeal for proselytising, until 
Hadrian forbade circumcision. Any one of Rome's nine synagogues may therefore have counter-attacked the Christian mission after the deaths of her leaders, Peter and Paul, under Nero, and succeeded in enticing some of her members back to a patriarchal form of worship.

So far the theories mentioned have had one thing in common: they recognise the Jewish nationality of the readers. A change of front came over criticism of the Epistle when E. M. Röth maintained that it was intended for Christians of Gentile extraction. Their peril, in his view, lay not in reaction towards Judaism, but in falling away to unbelief, or in disappointment with religion generally, or in succumbing to Hellenistic mystery cults and angel worship. More recently E. F. Scott and James Moffatt have popularised this new approach. They have stressed the absence from Hebrezes of all reference to the early controversies about Jew and Gentile circumcision, the Law, faith and works; they have argued that the Jewish priesthood and cultus were not living issues among the Jews in Rome in the ist century A.D.; and they have insisted that the great use made of LXX quotations does not prove that the readers were Jewish Christians, since the LXX was the Bible of the whole church.

Valuable as Dr. Moffat's Commentary is for its rich knowledge of Philo and the Wisdom literature, it fails to explain why a Gentile Christian group, in peril of apostasy, should be treated to irrelevant arguments about Melchizedek and Psalm i Io. There is abundant material in the LXX about the gods of paganism and demon sacrifices, and about atheism; and Alexandrian polemic against the inanities of Gentile polytheism provided the Christian apologist with ample answer to a sideslip into heathenism. Yet in fact there is not a word in Hebrews about unbelief in the sense of irreligion pure and simple, nor about pagan rites and mysteries, nor about the moral aberrations of Hellenistic society. The argument for Christianity is presented exclusively in terms of its relation to Judaism.

The essential weakness of Dr. Moffatt's case at this point has recently convinced Prof. W. Manson that the community of Christians established at Rome was predominantly Jewish not Gentile in character. He feels that the Christian mission owed 
a great deal to the eschatology of Stephen, who first grasped the more-than-Jewish Messianic office of Jesus. Stephen had perceived the universal range of the Christ-event, whereby the call of God had passed from the Jewish people to embrace humanity at large. While the Hebrew Christians gathered round the Apostles were still continuing steadfastly in the Temple, he saw that Messiah was really on the throne of the Universe: hence Temple worship, sacrifices, and Law, and all holy institutions of the past were transcended: the call of Christ's Church was to leave the Temple and historical securities of the Jewish cultus behind, and to go forward: to proclaim the Son of Man to every nation in the larger world of humanity, rather than to wait for Him to return to Jerusalem. The mobile tabernacle of Israel, featuring both in Hebrews and in Stephen's speech, typified the ever-onward call of God to His people, far better than the static temple ever could.

The impact of the world mission inaugurated by Stephen was felt in Rome by 49 A.D., when Suetonius attributes the Claudian expulsion of the Jews (Acts xviii.2) to the 'Chrestos' riots. These may have been the original hardships suffered by the Jewish Christians in Hebrews x.32-4. The Jews in Rome, when evangelised by the Christian mission, would not all immediately dispense with their obligation to the sacrificial cultus at Jerusalem. Indeed as late as Acts xxi St. Paul himself was associating with his Jewish brethren in ritual acts and vows. There may well have been a minority in the Roman Church who, in reaction from the larger freedom of the world-mission gospel, were asserting the position of the Hebrew section in the Jerusalem Church. Their tendency, though natural, was retrogade; it missed the reality of the Christian message; they were drifting away, losing their hold on the Christian salvation.

With these various theories of the nature of the apostasy briefly defined, it now behoves us to glance at some of the more emphatic admonitions in the Epistle, and let them speak for themselves. In the first of these (Heb. ii. I-5) the writer uses a nautical metaphor:

'We must pay closer attention to what we have heard, lest we drift away from it.'

He names no special rival attraction to the Christian faith; but 
emphasises that a revelation declared by Christ Himself, and evidenced by miracles and spiritual gifts, has a supreme claim to consideration. He contrasts it with the message delivered by angels. The prominence given to Christ over the angels, both here and in the opening chapter, has sometimes promoted the hypothesis that the community was tempted to angel-worship (a very real peril to converts reared in the Mazdaism of the Jewish Sect of the Covenant): or alternatively was in danger of falling away to syncretistic pagan religion, which, like all pagan life, the Jews held to stand under the government of angels (Deut. xxxii.8). But neither to Colossian angel-worship nor to astral religion is there any definite allusion in the rest of the Epistle. It seems therefore more likely that the writer is thinking of the angels as the mediators of the Law (Gal. iii. I9), as Stephen did in Acts vii.53, and that the fascination exercised by the Jewish Law was drawing the community into apostasy, whether in Rome or in Palestine.

A second passage is found in iii. $1-3$ :

'Therefore, holy brethren, you who share the heavenly calling, consider Jesus the Apostle and High Priest of our confession . . . Jesus has been counted worthy of a higher glory than Moses. ...'

Here the holy brethren would almost certainly seem to be Jews, whose Apostle was Jesus, in contradistinction to the Gentiles whose Apostle was Paul. In fact in Judaism, the high priest on the Day of Atonement was recognised as the Shaliach or Apostle of God. Their designation as 'consecrated' brethren with a heavenly calling may well describe their status as priests in Moses' house. Their calling is not to remain in the house, whether of the Law or of the Temple, but to move out into the more honourable house built by Jesus. It might be that iii.9, with its reference to 'forty years', is a veiled hint to some Qumran priests that it is useless to wait forty years from the death of the Teacher of Righteousness for the signal to move from the House of Exile to the control of the Jerusalem Temple; this would constitute, not a return to rest, but an apostasy from the Living God to whom they have so far been so faithful. At least the forty years yield a significant clue to the date of Hebrewes; and the general assertion must hold good, i.e. that the 
Christian life is a new Exodus, an onward march; and that the march begun must continue, rather than halt at some point midway between Judaism and Christian salvation.

There follow a series of short warnings related to the crisis in which the readers find themselves (iii. I 2 - iv. I3). Unbelief for example may result in departure from the 'Living God' (iii. I 2). Thus must surely refer to the God of Judaism, of whom Gentile pagans had hitherto been ignorant. Rebellion against Christ exposes Christians to that same Divine displeasure as fell on the very people whom Moses led originally. This same example of disobedience is admittedly used in warning a mixed congregation at Corinth ( $\mathrm{I}$ Cor. x.); but that does not render it irrelevant to a wholly Jewish body forsaking Christ for the Mosaic wilderness. What is certain from this section is that faith in Christ as the Pioneer and Perfecter of Christian living is the one essential to the attainment of His Rest.

In V. I I-I 2 the author characterises his readers as those who ought to be teachers. Two other N.T. passages spring to mind: James iii. I, where Christians are for the most part warned against desiring to be teachers; and I Cor. iii. I, where a similar contrast between milk and solids is introduced. For the Hebrew Christians the foundation principles about ablutions and laying on of hands have long ago been laid (vi. I-2). It is very tempting here to regard the addressees as priests from the Qumran Sect, who not only were familiar with the Purification rites of Judaism, but also practised a kind of Confirmation ceremony. Such priests in Judaism had a duty to teach, and could perhaps master the 278 O.T. references in the Epistle, and the involved instruction on the minutiae of the Jewish Tabernacle cultus. Be this as it may, the writer is not recommending an excursion into Gnosticism, only an advance to Christian maturity as in I Cor. ii.6. This advance can come much more easily to Jewish converts, even to such as Apollos or the Ephesian group in Acts xix, than to Gentiles who had never had the elementary principles instilled in early life.

The most famous passage historically now confronts us, i.e. vi.4-6, and Tertullian's approval of its denial of a second repentance looms large. But for our purpose two factors should be noted. First, the believers became participants of the Holy 
Spirit. This issue is reminiscent of the Ephesian group in Acts xix who did not even know about the Spirit. Clearly the Hebrews group had gone much further: they had shared in a Pentecost, where, as in Acts ii, the Spirit and the Last Days had been closely linked. Secondly, their apostasy amounted to reidentification with those who crucified Jesus, i.e. with the Palestinian Jews. The writer can only hope that such a catastrophe is more hypothetical than real.

The passages in chapter $\mathrm{x}$ have already been mentioned briefly. In verses I9-24 the writer presents the whole pattern of Christian life as worship. It is an approach through the Veil to the Holy Presence of God, made possible through a true ablution of baptism and the blood of Jesus. The appeal of such teaching would come with extreme vividness to priests who had ministered either at the Jerusalem Temple or at Qumran; for it sees worship as the priest sees it, as the norm of life. The verse which follows (25) is open to many interpretations.

'Let us not discontinue meeting together as the habit of some is,

Rather let us exhort each other, the more so as you see the Day drawing near.'

It has been used of Gnostic Christians seceding from the Church, or of conservative Jewish Christians, giving up the Christian meetings on the ground of their freedom from ceremonial observance. The Day may well be that of A.D. 70 .

x.26-30 returns to the theme of vi.4-6. A deliberate contempt for God's revelation in Christ will involve retribution more terrible than the death penalty attaching to defiance of the Law of Moses. It is repudiation both of the baptismal confession of Jesus as Son of God (possibly accompanied by the actual statement that Jesus is Anathema), and of the New Covenant, which the Qumran priesthood especially upheld, and which Jesus sealed with His blood. Almost certainly it involves a return to the Old Covenant of Judaism.

Finally in x.32-39 the author recalls the readers' loyalty in the former days of persecution, whether in A.D. 49 or in the time of Stephen; he makes a last appeal to them not to fling away their reward, and reiterates Stephen's faith in the world mission of the Church which must anticipate the near return of Christ. 
Any conclusion reached on the nature of the Apostasy in Hebrews must be tentative, in view of our uncertainty as to the document's date and destination. The balance of the evidence would suggest that the readers were Jewish Christians, who were tempted to return to Judaism instead of advancing to Christian perfection. There seems no very grave objection to the recent suggestion that they were the company of priests in Acts vi.7, or even that they emanated from Qumran. They may even have hoped, as the true sons of Zadok, to establish themselves in the Temple at Jerusalem when the day of A.D. 70 actually dawned.

For ourselves, however, the warnings about drawing back and flinging away our Christian reward remain as pertinent as ever. Though Judaism may exercise none of its ancient fascination for the Christian Church, she will never be short of the faint-hearted and the backsliding, nor of those who shirk the responsibility of teaching. The age-long peril of apostasy will be countered only by the age-old practice of this inspired writer:

'By looking unto Jesus, the author and perfecter of our faith.'

\section{Tertullian on Prayer}

\section{by Dr. O. W. Holmes}

THE FACT that the Tyndale Fellowship exists "for Biblical Research" is not intended to restrict the interests of its members to a narrow interpretation of the phrase, as is evidenced by the existence of its Church History Group, which yields evidence of light shed down the ages by those who have found in our Scriptures the source of their message to their day and age.

We have, in the Church of Carthage of Tertullian's day, almost a perfectsubject for the detached study of the place which prayer occupied, or should occupy, in a church whose very founder (if it had one) we do not know, living close (but not too close) to the cradle of the Christian faith in both time and place, as seen through the eyes of a man originally a member of 